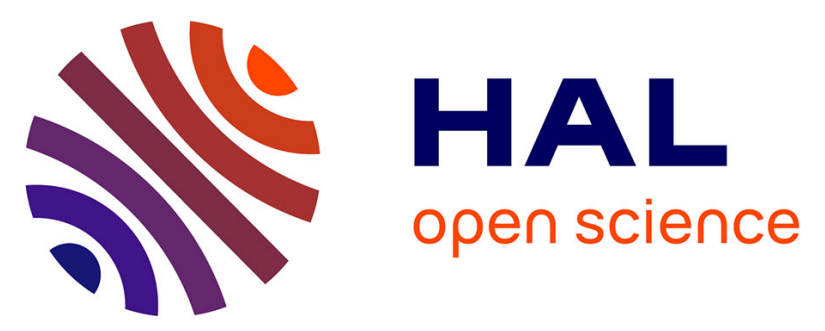

\title{
Food safety management through the lens of hybrids: the case of fresh fruit and vegetable shippers
}

\author{
Jean Marie Codron, Alejandra Engler, Cristian Adasme, Laure Bonnaud, \\ Zouhair Bouhsina, Gabriela Cofre-Bravo
}

\section{To cite this version:}

Jean Marie Codron, Alejandra Engler, Cristian Adasme, Laure Bonnaud, Zouhair Bouhsina, et al.. Food safety management through the lens of hybrids: the case of fresh fruit and vegetable shippers. Management and governance: franchising, cooperatives, and strategic alliances, Editions Springer, 322 p., 2017, Contributions to Management Science, 978-3-319-57276-5. hal-01603056

\section{HAL Id: hal-01603056 https://hal.science/hal-01603056}

Submitted on 5 Jun 2020

HAL is a multi-disciplinary open access archive for the deposit and dissemination of scientific research documents, whether they are published or not. The documents may come from teaching and research institutions in France or abroad, or from public or private research centers.
L'archive ouverte pluridisciplinaire HAL, est destinée au dépôt et à la diffusion de documents scientifiques de niveau recherche, publiés ou non, émanant des établissements d'enseignement et de recherche français ou étrangers, des laboratoires publics ou privés. 


\title{
Food safety management through the lens of hybrids: \\ The case of fresh fruit and vegetable shippers
}

\author{
Codron, J.M. ; Engler, A. ; Adasme, C. ; Bonnaud, L. ; \\ Bouhsina, Z. ; Cofre-Bravo, G.
}

\section{VERSION POST-Print}

In : Hendrikse, G.W.J. ; Cliquet, G. ; Ehrmann, T. ; Windsperger, J. (eds). Management and governance of networks. Franchising, cooperatives, and strategic alliances. Springer, 2017, 295-322

https://dx.doi.org/10.1007/978-3-319-57276-5 


\title{
Food safety management through the lens of hybrids: The case of fresh fruit and vegetable shippers
}

\author{
Jean-Marie Codron', Alejandra Engler, Cristian Adasme, Laure Bonnaud, \\ Zouhair Bouhsina and Gabriela Cofre-Bravo
}

\begin{abstract}
Managing the pesticide safety risk to provide end markets with safe fruit and vegetables raises complex issues due to the diversity and stringent nature of public and private safety requirements and the high cost of controlling the product and the production process. More often than not, this leads to the development of diversified and more integrated relationships between growers and their buyers. Our paper is a case study of the hybrid forms underlying such relationships. It begins by developing the analytical framework, drawing on Transaction Cost, Positive Agency and Property Rights theories with a special focus on the model proposed by Ménard (2013), positioning the hybrid forms along the two dimensions of decision rights and strategic resources. It then presents a selection of quantitative and qualitative findings obtained from data collected through face-to-face interviews with managers of fresh produce shipping firms in France and Chile. Both case studies confirm that the level of centralization increases with the buyer's commercial reputation, the level of customer safety requirements (a key component in the marketing strategy of the buyer) and the level of asset specificity which is mostly embedded in the technical assistance and training provided by the buyer to the growers. Moreover, our paper establishes a clear divide between firms that only control product safety at the delivery stage and firms that also control safety throughout the production process and may take decisions on behalf of the grower before harvesting.
\end{abstract}

Dr. Jean-Marie Codron, French National Institute for Agricultural Research, UMR1110 MOISA, 2 Place Pierre Viala, 34060 Montpellier Cedex1, France; Phone+33499612305; Email: codron@supagro.inra.fr Pr. Alejandra Engler. Department of Agricultural Economics, Faculty of Agrarian Science, University of Talca, Lircay s/n Talca, Chile; Phone+56712200214; Email: engler@utalca.cl

Pr. Cristian Adasme-Berríos. Department of Economy and Administration. Faculty of Social Science and Economy. Universidad Católica del Maule. Avenida San Miguel 3605. Talca. Chile. Phone: +5671203563; Email: cadasme@ucm.cl.

Dr Laure Bonnaud, French National Institute for Agricultural Research, UR RiTME, 65 Boulevard de Brandebourg, 94200, Ivry-sur-Seine, France; Phone +33149596996; Email: laure.bonnaud@ivry.inra.fr Dr. Zouhair Bouhsina, French National Institute for Agricultural Research, UMR1110 MOISA, 2 Place Pierre Viala, 34060 Montpellier Cedex1, France; Phone +33499612052; Email: bouhsina@supagro.inra.fr

Dr. Gabriela Cofre-Bravo, Department of Agricultural Economics, Faculty of Agrarian Science, University of Talca, Lircay s/n Talca, Chile; Phone+56712200214; Email: gcofre@utalca.cl. 


\section{$1 \quad$ Introduction}

Food scares and consumers' suspicions concerning pesticides has led to the development of public and private standards relating to the use of pesticides in agricultural production and to the pesticide residue levels not to be exceeded when marketing the products (Codron et al, 2005; Fulponi, 2006). They have also led to stricter control of these standards by both the public authorities and the private sector. At a European level, a thorough review of food regulations gave rise to the General Food Law (Regulation R178/2002 which took effect ton January 1, 2006) which henceforth required all operators in the supply chain to check the safety of the products on sale, and in particular their compliance with the residue standards (Rouvière and Latouche, 2014).

This obligation primarily concerns the first trader, i.e. the operator in the value chain immediately after the producer. The former was required to define more stringent rules than the public regulations, to impose best practice standards requiring thirdparty certification and to revise the control and monitoring procedures implemented by their suppliers. Over a period of ten years, the simple control of the product and the best practice certificates approved by third parties became a more complete and more complex control also targeting the production process and implemented directly by the buyer.

In the fresh produce sector where pesticides are the main concern for human health, buyers facing stringent pesticide safety requirements do not limit their control to the product itself (pesticide residue analysis at the platform level) but are also involved in controlling the production process (monitoring and often taking decisions with regard to certain production practices). The more tightly-meshed coordination desired for this type of control is all the more necessary as perishability must also be managed. With the development of health requirements in the fruit and vegetable sector, we therefore observe increased integration in the transaction between the producer and his buyer, often reflected by the transfer of decision and control rights from the producer to the buyer.

From a theoretical point of view, such coordination issues are better governed by hybrid forms and sometimes hierarchical forms which develop as substitutes for the previously dominant market forms. According to Transaction Cost Theory, hybrid forms or hybrids are intermediate forms between market and hierarchy. They combine market incentives and coordination rules (Williamson, 1991). More insightful is the characterization by Property Rights scholars who suggest modelling these intermediate forms by differentiating decision rights from property rights and looking at the allocation of these distinct rights among the parties to a transaction (Baker and al, 2008; Ménard, 2013). Hybrid forms can first and foremost be explained by a need to improve coordination while managing the risk of opportunism linked to the use of strategic or specific resources. They can be analyzed as in the simplified model put forward by Ménard (2013) which calls on both TCT and property rights theories according to the two main determinant 
variables: the level of strategic resources or specific assets pooled in the transaction and the level of centralization of the controls or decisions when completing the transaction. In particular, this makes it possible to go beyond the simple dichotomy between the market and hybrid forms or hybrid forms and integration and to differentiate hybrid forms according to the specific assets and the allocation of property rights, two criteria which are pivotal to TCA and PR theories respectively.

According to Ménard (2014), however, few works have made it possible to specify Ménard's model and to test the relationship that exists between the allocation of rights and the strategic resources pooled. Our paper contributes to bridging this gap by producing a health risk management model in the relationship between fruit and vegetable producers and shippers enabling the two key variables of Ménard's model to be specified and the relationship between these two variables predicted by Ménard's model to be tested. The model is specified and tested using data collected by means of two face-to-face surveys, one conducted in France with 20 groups of tomato producers (Codron et al, 2013) and the other conducted in Chile with 33 fresh fruit exporters (Engler et al, 2016). Our survey highlights a diversity of hybrid forms which can be characterized by the degree of centralization of the main safety strategic decisions (residue controls on the products, control of the production process). We show that such diversity depends not only on the safety-specific strategic resources but also on certain general organizational and marketing strategic choices.

Our paper is organized as follows. Section 2 develops our analytical framework, based primarily on the Transaction Cost, Organization and Property Rights theories with a special focus on the model proposed by Ménard (2013) positioning the hybrid forms along the two dimensions of decision rights and strategic resources. Section 3 specifies Ménard's model in the case of managing the pesticide safety risk in the fresh produce sector. To this end, it identifies the nature of the transactional issue and builds on the analytical framework to characterize the allocation of decision rights and formulate hypotheses concerning the factors influencing this allocation. Section 4 is an empirical test of the predictions of the theory, based on the data collected through face-to-face interviews with firm managers in two case studies (French tomato shippers and Chilean fruit exporters). It aims to explain why safety controls are performed through a diversity of hybrid forms. Section 5 compares the two case studies, highlighting the key theoretical and empirical contributions of our paper, its managerial implications and the associated limitations. Section 6 concludes and suggests avenues for further research.

\section{Analytical framework of the hybrid forms}

Safety management pursues two different and contrasting objectives: on the one hand it aims to minimize control costs by providing incentives and the appropriate coordination rules in order to avoid agent opportunism, free-riding or shirking and 
to protect specific investments against the threat of hold-up by the other party to the transaction. On the other hand, it endeavors to maximize the creation of value by pooling specific resources and encouraging learning or the development of skills while minimizing the coordination costs necessary to adapt to exogenous uncertainty. Although both objectives are usually pursued by the firms included in our survey, we have focused on rent appropriation and the governance solutions that help minimize control costs, leaving the magnitude and impact of the other objective for further research.

Different bodies of literature have addressed the issues of transaction costs and rent appropriation by considering the diversity of governance solutions, their legal status, structures, mechanisms and performance and elaborating hypotheses concerning the factors influencing the choice of a governance solution. Among the most influential are TCT (Transaction Cost Theory) and PAT (Positive Agency Theory). The TCT branch of governance (Williamson, 1991), which is the most influential, focuses on asset specificity and the consequent threat of hold-up over the rent derived from the implementation of specific assets. Solutions to overcome such contractual hazards have been extensively studied in Transaction Cost Theory (for literature surveys, see for instance Shelanski and Klein, 1995; Macher and Richman, 2008). The prediction in a context of radical uncertainty is that the greater the asset specificity, the more integrated the governance structure of the transaction will be.

Additional insights have been given by Barzel, who is identified as a leader in the field of measurement in TCT (Williamson, 1985), and scholars of the Positive Agency Theory (Jensen and Meckling, 1976; Fama, 1980; Eisenhardt, 1989). Both theories raise the issue of measurement costs for the organization of a relationship. In the former, a main source of measurement cost is the difference in expertise when estimating the value of the good which may lead to a risk of information manipulation by the party with more expertise. The Positive Agency Theory emphasizes monitoring expenditure by the principal, bonding expenditure and residual loss in organizations featuring tasks exhibiting non-separability and/or low programmability. While non-separability deals with the difficulty in measuring certain attributes of the output, low programmability relates to the production process and the difficulty in programming certain important decisions ex-ante, in the contract or the agreement, which condition the performance of the transaction, , . A main result in both theories (TCT branch of measurement and PAT) is that the higher the measurement costs, the more integrated the governance structure. Of course, both asset specificity and measurement costs may be important issues in the transaction at stake. Considering the complementary predictions of TCA and PAT, Mahoney (1992) built a predictive matrix of the solutions arising from variations of asset specificity, output separability and process programmability.

Property Rights theories (Grossman and Hart, 1986; Hart and Moore, 1990) allow for a complementary analysis of the institutional arrangements by focusing on decision rights and relating them to ownership rights. They help explain the 
structure of residual decision rights by the distribution of assets that generate the firm's residual surplus. Barzel $(1989,2005)$ and Ménard (2013), who both claim to belong to TCT and more widely NEI, also contribute to the development of PropertyRights theories by combining the two theories to predict the choice of governance structure. Barzel, who focuses on measurement costs as a main source of transaction costs, predicts that parties faced with high measurement costs, will allocate control and decision rights to the party with more expertise, provided that the party with less expertise, which abandons some control and decision rights, is given guarantees concerning the sharing of the quasi-organizational rent.

Ménard (2013), who clearly sides with Williamson's thoughts, oriented a large part of his work towards the analysis of hybrid forms, the modalities of their governance and the factors explaining the choice of these modalities. Drawing on Property Rights theories, he clearly differentiates hybrids from markets and hierarchies and defines them as arrangements where "key rights are in the hands of autonomous partners who retain titles as residual claimants, while subsets of assets, rights, and associated payoffs are shared and monitored jointly". He then observes that there is, in reality, a broad diversity of hybrids such as franchising, strategic alliances and cooperatives (Ménard 2013, chapter "a short visit to the zoo"), but notes that "efforts for capturing the specificity of the arrangements within a coherent analytical framework remain underdeveloped". He thus calls for a transversal model that would allow the different categories of hybrids to be analyzed with a few key concepts. To develop such a model, Ménard refers to the works of the Property Rights Theory, and in particular to the model proposed by Baker et al (2008) who suggested modeling alternative organizational arrangements by differentiating decision rights from property rights and looking at the allocation of these distinct rights among parties to a transaction.

Ménard goes a step further by providing a simplified model based on the central prediction of the Property Rights theories saying that the greater the pooling of ownership rights, the higher the level of centralization (or pooling) of decision rights between the parties. In this two-dimensional model (figure 1), the horizontal axis measures the level of strategic resources and associated ownership rights that might be pooled while the vertical axis is defined by the level of centralization in the coordination and control of the pooled strategic resources, a level which may be deemed a good proxy of the regime of allocation of the decision rights.

The link with the theory of transaction costs is clear. On the horizontal axis, the strategic resources may be considered as the specific assets in the Williamson terminology. They also may include the knowledge, skills or expertise that help reduce measurement costs as underlined in Barzel's TCT branch of measurement or in the Positive Agency Theory. On the other hand, the level of centralization or decentralization of decision rights may be seen as a key feature of the governance structure. We thus retrieve the central prediction of Williamson, establishing a relationship of causality between asset specificity and the choice of governance structure. 
This model makes it possible to posit hybrids and differentiate them according to the intensity observed in sharing both types of rights. Three types of governance of hybrids are identified, corresponding to a specific coordination device and at the same time to a different allocation of control and ownership rights: informationbased networks, third-party coordination and strategic center. Hybrids relying on information-based networks are the least centralized systems and have little or no pooled strategic resources while hybrids having established a strategic center, which may be one of the two parties or a common entity, are the arrangements with the highest level of decision centralization and the highest rate of pooled assets. Thirdparty-coordination hybrids are an intermediate type.

Relational contracts add to the governance mechanisms of decision rights allocation. They play a significant role in coordinating and enforcing hybrid arrangements. Because of the importance of non-contractible elements in the hybrid arrangement, there is a need for tightly-meshed relations to limit the impact of a) imperfect and costly information, b) opportunistic behavior and c) difficulties for outsiders to enforce agreements plagued with non-verifiable elements (Goldberg, 1980; Baker et al, 2002). Relational contracts thus help maintain stability and efficiency and delineate a zone of tolerance and acceptance below the optimization frontier; this area, represented as a lens on the graph, has a lower boundary (dotted line) below which a hybrid loses efficiency and can no longer survive.

\{Insert Figure 1 about here $\}$

\section{The specific pesticide safety management model}

The Ménard model is useful in giving analytical insights into the management of the pesticide safety risk in the fresh produce sector and describing the hybrid form underlying such management. A preliminary step in this description is to characterize the nature of transaction costs and the sources of transaction costs (specific assets, uncertainty, reputation and collective action) before identifying the appropriate mechanisms to govern the safety objective and the significance of their role in the governance structure.

\section{Nature and sources of the safety transaction costs}

Before safety quality became a crucial dimension of the transaction between a producer and a buyer, relationships were managed with market or close-to-market mechanisms. Buyers' requirements focused mostly on volume, commercial quality and logistics. Since all these transaction attributes were easy to measure, there was no need for incomplete contracts. Complete contracts with pure incentives were sufficient to govern the relationship and provide buyers with the required characteristics. With the development of pesticide safety requirements one or two decades ago, significant changes have occurred in the farmer-buyer relationship. 
Transaction costs, which were previously very low, have significantly increased and have become pivotal to the choice of control strategy.

Transaction costs are basically derived from an agency issue where the goals of the farmer (maximizing yield) may conflict with the goals of the buyer (compliance with safety rules) and where deviant behavior is difficult to detect given the strong exogenous hazards. Farmers may thus be reluctant to reveal information or to produce information that may be useful to the buyer with regard to safety management. For instance, a farmer may prefer to use a forbidden pesticide which is cheaper and may have a stronger impact on the pest but which is not accepted by the buyer for regulatory or customer-related reasons. To reduce such agency costs, buyers may choose to focus their controls on the product or the production process.

Controls implemented on the product to detect pesticide residues are costly (Ruben et al, 2007), if not prohibitive if applied to all products delivered by the growers. This leads buyers to use sampling and penalties to enforce compliance with safety requirements. However, given the complex production function and the high level of environmental uncertainty, it is difficult to distinguish between a grower's efforts and hazard and thus to draft a complete contract and determine the optimal sanction which could lead a grower to make the "utmost effort" required by the buyer. Consequently, most buyers are encouraged to draft incomplete contracts and to monitor growers' efforts in the production process.

Controls targeting the production process mean high transaction costs, due mainly to uncertainty and asset specificity. Uncertainty derives from the complexity of the production function and the difficulty in evaluating the right decision (Codron et al, 2013) for some key pest and disease management activities. Decisions concerning activities such as chemical spreading or the introduction of biological auxiliaries are so complex and contingent on fluctuating parameters which have to be measured at the last moment that they cannot be defined ex-ante and have to be taken at short notice. Such uncertainty is also observed in the literature as (low) ease of measurement (Williamson, 1991), difficulty of measurement (Barzel, 1982) or low task programmability (Ouchi, 1979; Eisenhardt, 1985). Allocation of monitoring and decision rights to the party best informed (Barzel, 1989) allows such uncertainty to be reduced but, at the same time, creates new transaction costs referred to as "errors of measurement" by Barzel (2005) and relating to the possible manipulation of information by the party which has been allocated control and decision rights. In our case study, it is usually the buyer who is granted this allocation as he is the better informed due to his market knowledge and his greater resources to recruit technical advisors. Of course, there is variation in this allocation of decision rights. While the buyer usually decides the phytosanitary program, he may allow some leeway in the application of the program, depending on a grower's phytosanitary skills and the buyer's technical resources.

Asset specificity is mainly embodied by the human resources that the buyer invests to perform his controls of the production process. Most buyers recruit technicians 
with some knowledge of IPM to recommend or impose actions to be taken by the grower. Given the exogenous uncertainty and the difficulty in monitoring the grower, there is potential for grower opportunism and a risk of poor efficiency on the part of the technician. Drawing on the literature on the allocation of property rights (Barzel, 1989) and asset specificity (Williamson, 1991), the risk of maladaptation or abusive appropriation of the quasi-organizational rent created in the grower-buyer transaction increases with uncertainty (or difficulty to measure), asset specificity and the safety level targeted by the buyer.

A third class of transaction costs has to be considered for the protection of the commercial brand or reputation of the buyer. If the buyer is a private firm, the brand may be considered as a specific asset which has to be protected from grower opportunism. If the buyer is a marketing group, the brand is a collective good which generates free-riding and exclusion costs. Such transaction costs increase significantly with the development of safety, as reputation now depends on the capacity of the private firm or the marketing group to deliver a safe product, which is a relatively costly affair. The rules to comply with customer requirements are indeed difficult to define and monitor while the incentives to reward safety performance are almost non-existent. Before safety became a commercial issue, the costs for building and protecting a commercial reputation were mostly production costs and less so transaction costs. It was indeed much easier to control for opportunism or free-riding when delivering the product as the attributes (size, color, packaging, etc.) were easier to measure and reward. As a result, coordination with suppliers was mostly governed by incentives and there was little need for the allocation of control/decision rights.

A fourth class of transaction costs exists in the case of marketing groups since, according to Olson, free-riding costs increase with the size of the group. Of course, traceability helps identify the defaulting grower and alleviate the responsibility of the group. Best agricultural practices standards, such as Global Gap or Tesco, help improve individual behavior and mitigate the risk of opportunism. However, they do not totally exonerate the buyer or the group which is deemed responsible for grower control, must justify such a flaw and may suffer damage to its commercial reputation. We can therefore expect that the delegation of authority, which helps reduce transaction costs, will increase with commercial reputation and, in the case of marketing groups, with the size of the group. This is in line with the emerging literature on contract design focusing on the allocation of control/decision rights (Arrunada et al, 2001; Hu and Hendrikse, 2009).

\section{Governance structures and mechanisms}

In the model proposed by Ménard, the allocation of decision rights is equated to a governance structure and the strategic resources to specific assets. However, the allocation of decision rights that we adopt as a solution to manage the health risk cannot be equated with the entire governance structure. This specific allocation is actually one governance mechanism among others in the governance structure 
governing the transaction between the producer and his buyer (Bijman et al, 2013). We must therefore ensure that the other governance mechanisms will not have a significant impact on the relationship we assume exists between the allocation of decision rights to manage the health risk and the strategic resources implemented to manage this health risk.

In both situations studied, we have observed that other governance mechanisms may play an important role in characterizing the governance structure or the level of centralization of the decision-making process. This is particularly the case for the allocation of rights for product commercialization or the management of the commercial quality of the products.

The allocation of rights relating to marketing decisions exists in particular for negotiations with potential customers and the assignment of production to meet the customer demand. In a simple grower-buyer relationship, the marketing decision more often than not belongs to the buyer who is entrusted by the grower to sell his product. In the fresh produce sector, there used to be frequent transfers of decision rights from the grower to the shipper for product commercialization. This is true for cooperatives or producers' organizations which mandate a marketing manager to sell their products. This may also be true for private buyers when there is a need to sell on consignment, which is the case in the Chilean case study. Selling on consignment is a common method of selling for long-distance exports by boat, for instance from Valparaiso to Rotterdam, where the minimum duration is 21 days. In such conditions, it is not possible to fix a firm price in advance at loading due to the high price volatility on this market. As a result, consignment is still the most widespread means of selling fresh produce for these long distance exports by boat. Although the grower remains the owner of the fruit, consignment means that he has to abandon his decision rights for selling the product to the shipper (exporter), who himself often transfers the marketing decision rights to an importer.

The allocation of decision rights concerning the sale of the products may lead to certain information asymmetries, in particular when the buyer is a private entity. There are nevertheless numerous strategies available to the producer to reduce this information asymmetry (prices regularly communicated by the buyer throughout the season, informal producer networks creating a certain transparency with regard to the prices obtained from different buyers, producer organization centralizing invoices for a season and render each individual price in relation to reference prices, etc.). Rights are therefore allocated not to reduce transaction costs but to reduce production costs. If rights are allocated for the commercialization, this is done for reasons of efficiency and economies of scale as effective commercialization requires both large volumes and specific competences without this leasing to high transaction costs. It is crucial to note that in both cases (marketing group and private buyer), the transfer of decision and control rights only concerns the commercialization of the product and does not extend to the production of this product. 
Governance mechanisms could also be envisaged to manage the commercial quality of the product (size, color, faults, sugar level, etc.). As these characteristics are easy to measure, the commercial quality of a product at delivery is often transparent for both parties and is not subject to manipulation by the buyer. Nor does the buyer gain any advantage by deciding how these characteristics are produced instead of the producer as the price mechanism and the commercial quality standards are very effective in guiding the producers' actions. The allocation of decision rights with regard to the production process is therefore almost non-existent. The buyer simply provides market information and indicates his customers' preferences which result from his commercial strategy. Commercial quality is therefore primarily managed according to a "price"-type governance mechanism and is generally not the subject of an "allocation of decision rights" type of governance.

The transfer of decision/control rights may be much more extended as soon as there are safety requirements at stake. Such a transfer is primarily used to reduce the transaction costs linked to the difficulty of measuring the product or programming the production process. As a matter of fact, it is difficult and costly to measure product safety and thus to define incentives to reward safety performance. For the same reasons, products with excess residues due to exogenous hazards are not punished and receive the same price as compliant products. It is therefore much more efficient to complement product monitoring by monitoring the production process. However, the latter remains a difficult task to perform. Many decisions concerning the production process cannot be planned in advance and have to be taken at short notice. This is true of chemical treatments or integrated pest management. In line with the theoretical prediction of Barzel (TCA branch of measurement) and Mahoney (PAT), non-programmability may lead to a transfer of decision/control rights to the party with more expertise accompanied by compensation for the other party to the transaction. In our case, the difficulty of programming crucial actions such as IPM may lead to a transfer of control/decision rights over the production process to the buyer who clearly has much more information concerning the customers' safety requirements than the grower and, more often than not, enjoys better technical expertise than the grower.

As a first approximation, we have thus assumed that the allocation for the management of health quality leads to the highest possible involvement of the buyer in the producer's decision concerning production. In multi-tiered structures (cooperatives or private exporters) with a transfer of control and decision rights concerning the production process, the issue is how the rights are allocated among the different tiers of the structure. Strategic decisions, such as the phytosanitary program to be imposed on the growers, are usually taken at the central level which has the best information concerning customers and their safety requirements and where branding activities take place. Conversely, most decisions relating to the application and adjustment of safety programs to local hazards (pest pressure, climate, etc.) are much more efficient when they are taken at the local level by intermediate structures which are better informed about the idiosyncratic characteristics of the problem. Retaining local information and taking account of 
the fact that the intermediate structure remains a key level of decision-making for safety management, every intermediate structure has been surveyed and considered as a unit of analysis, even though they belong to a superstructure dictating strategic orientations.

\section{A tentative model for safety management in the fresh produce sector}

In conclusion, to reduce the risk of finding a product with excess residues over the legal limit (maximum residue limit) or over the private standard imposed by the retailer, the transfer of control/decision rights in the fresh produce sector is not always restricted to the commercialization of the product and often extends to the production process as soon as there is a need to comply with customer safety requirements. Conversely, the transfer of control/decision rights is more limited when there is little concern for safety and when the main focus is on commercial quality (size, color, packaging, etc.). Given that commercial quality is much easier to measure than safety quality and may be rewarded with incentives defined ex-ante by the buyer, transaction costs are lower. We therefore consider that the transfer of decision rights from the grower to the buyer mostly occurs with the development of private and public safety requirements and is much more extended and more costly in terms of transaction costs than traditional transfers implemented for the commercialization of the product. Drawing on the transactional, organizational and property rights theories, we can predict that this transfer is strongly oriented by the safety dimension of a marketing strategy, safety-specific assets, commercial reputation and group size.

\{Insert Figure 2 about here\}

\section{Empirical test of the relationship between decision rights and strategic resources: the case of tomato POs in France and fruit grower-exporter relationships in Chile}

Testing the prediction is a challenging task. While much has been written on buyersupplier relationships and the way they can reduce transaction costs, in particular ex-post monitoring and enforcement costs (Hueth et al, 1999), testing the choice of a governance structure is not easy, primarily due to the lack of relevant data or the small size of the samples (Hobbs, 1996; Sykuta, 2008). One of the problems is to know how to represent the governance structure. Several types of proxy have been suggested (see Shelansky, Sikuta) including duration, number of clauses, etc. In Ménard's model, the proxy is the level of centralization in the decision-making process. We deemed this suitable to represent the solution facilitating the management of health quality.

Only a few empirical studies (Arrunada et al, 2001; Windsperger, 2009; Hu and Hendrikse, 2009; Malatesta and Smith, 2015) have tested the relationship between 
the level of centralization and strategic resources. They show that the organization becomes more efficient (in terms of value added or reduction of transaction costs) when there is a good match between the distribution of decision rights and the set of strategic resources (specific assets such as knowledge assets, commercial reputation, level of quality, etc.) implemented by the parties of the organization. Our paper contributes to this empirical literature by focusing on the safety management systems of fresh produce grower-shipper dyads. It aims to test the predictions of the theories presented above. Within this theoretical framework, we can predict that the delegation of safety controls to the buyer, either the private buyer or the managers of the marketing group, will increase with the level of safety targeted by the buyer or the group, commercial reputation, asset specificity and possibly group size.

Hypothesis 1: More decision rights are assigned to the buyer, when the firm deals with high customer safety requirements.

Hypothesis 2: More decision rights are assigned to the buyer, when the commercial reputation of the buyer is better recognized.

Hypothesis 3: More decision rights are assigned to the buyer, if the level of buyer's specific investment increases.

Hypothesis 4: More decision rights are assigned to the buyer, if the size of the group of suppliers increases.

The four variables impacting the transfer of property rights are closely linked to safety management and are the result of strategic choices made by the private buyer or the marketing group. Moreover, we make a clear distinction between controlling the process and controlling the product, which are two different ways of transferring control rights from the grower to the shipper. Our hypothesis is that the two types of control are positively but differently impacted by the four variables mentioned above and that the intensity of each of the two controls also results from a strategic choice.

\section{Presentation of the case studies and sampling}

Two case studies with primary data collection were conducted to test the hypotheses. The first concerned 20 marketing groups of French tomato growers accounting for more than $95 \%$ of French tomato production with market organization (Codron et al, 2013). The second was conducted with 38 Chilean fruit exporters selected at random from the 79 exporters recorded by ASOEX, the Chilean exporter association, in O'Higgins and Del Maule regions which include the national leaders in the production of apples, pears, grapes and kiwi (Engler et al, 2016). The sample of export firms was obtained by means of a simple random sampling formula with a $95 \%$ confidence level and $12 \%$ standard error with $p$ equal to 0.5 . 


\section{Data collection and quality of the data}

In both surveys, data were collected by means of closed questionnaires and face-toface semi-structured interviews. The questionnaires considered five series of items: i) structures and marketing strategies of the buyer; ii) technical assistance and training of the growers; iii) private certifications such as Global Gap; iv) types of control of pesticide residues and penalties in case of non-compliance with buyer rules; and v) types of control over the process, grower production practices and how the latter are managed/monitored by the buyer.

It is worth mentioning the factors that may impact the quality of data collection in the field of safety. Safety issues are usually hot social topics for operators in the supply chain. Given the propensity of some mass media to deal with safety issues without taking the precautions required by the complexity of such issues, most operators are reluctant to communicate details concerning the measurement and results of their safety management, especially regarding residues. As a result, data collection is a difficult and very time-consuming exercise for scholars requiring considerable expertise and networking in the sector. The resources available for data collection are thus a crucial element in such research.

In the French survey, face-to-face interviews were conducted separately with the technical staff, the quality manager and the director of the cooperative/firm and were quite intensive (the average duration of each interview was about one and a half hours). In the Chilean survey, the interviews were shorter in time, conducted with only one person, most frequently the agronomist responsible for providing technical assistance to suppliers. The data collection therefore proved less fruitful and resulted in a lower number of significant items for analysis.

\section{Measurement of the dependent variables}

In the Chilean survey, the focus was on the safety risk management practices associated to MRL. Five discriminatory items were used to represent those practices: (1) number of residue tests per year per supplier (i.e. farm level producer); (2) payment of residue testing (paid by the export firm, by the supplier, shared payment); (3) the importance of MRL when selecting destination markets; (4) the moment when the destination market is decided (before harvest, during harvest or in packing); (5) timing of testing (before harvest or during harvest and at the packing arrival). Items 1) and 2) were related to the control over the product while items 3 ), 4) and 5) may be considered as proxies of the control over the process.

In the French survey, ten items serve as proxies to measure the dependent variables. The control over the product is documented by the number of residues analysis per grower per year and by six other proxies measuring the sanctions in case of default (type of penalty, incentives for grower transparency, communication of individual results at the collective level) and the procedures of control (grower sampling for residue analysis, at least one analysis per grower per year, information/association of the technician). To approximate the control of the buyer over the process, the 
following three proxies have been found discriminatory; i) frequency of greenhouses visits by the Quality Manager; ii) consultation between the Quality Manager and the IPM Technician over residue management and prevention; iii) type of management of the crop sheets and centralization of the information at the PO level.

\section{\{Insert Table 1 about here\}}

\section{Measurement of the independent variables}

In the French survey, nine items serve as proxies to measure the independent variables. Group size was measured by the number of tomato growers in the PO while the reputation of the group was approximated by means of three variables: the existence of an association of POs with a collective brand, the average value per kilo obtained by a PO during the year (total value/total production) and the level of segmentation measured by the percentage of "non-standard" tomatoes (small tomatoes, old varieties). Quality/safety targeted by the group was approximated by three variables: the existence of customers in the UK, the market share of the fast food industry and the existence of specific safety requirements in terms of pesticide residues. Two items were finally selected to represent asset specificity: the quality manager's profile and the IPM technician's profile: the former was defined by the level of professional education and the number of years' experience in this activity while the latter was characterized by his level of IPM involvement: strong involvement for technicians hired by the PO and fully dedicated to IPM, medium involvement for technicians hired by the PO and sharing their time between IPM and general technical assistance and low involvement when no technician has been hired.

In the Chilean survey, twelve items were used as proxies of the independent variables: three items for commercial reputation (export size, number of market destinations, number of fruit species exported), three items for the level of customer safety requirements (number of GAP certified suppliers, buyer certification (BRC or ISO), four items for asset specificity (general and safety specific technical assistance provided by the buyer, training provided by the buyer, number of growers per technical adviser), two items for group size and control of free riding (number of suppliers, use of contracts with suppliers).

\section{Analysis}

In the French case study, the following OLS regressions were run for each of the 10 variables of control over the 9 independent variables (see table 1). Given the differences in nature of the items, we used a series of combinatorial tests to assign a weight and aggregate the items associated to a given variable (dependent or independent). Resulting weightings were validated by experts.

Decision/monitoring Rights allocation ${ }_{i=1}$ à 10 $=\beta_{0}+\beta_{1}$ Size $+\beta_{2-4}$ Quality targeted $_{2-}$ ${ }_{4}+\beta_{5-7}$ Reputation $_{5-7}+\beta_{8} Q_{8}+\beta_{9}$ Technician $_{9}+\varepsilon_{\mathrm{i}}$ 
In the Chilean case study, a cluster analysis was used with the aim of defining groups of firms with similar characteristics of safety management practices within the group, but different between groups. The five practices mentioned above were used for the cluster analysis. Two clusters were obtained by means of a hierarchical method. Once the clusters and therefore the management strategies were defined, the influence of the independent variables was analyzed using a Chi-square contingency table.

\section{Findings}

In the French case study, we obtain results (see Appendix A1 and for more details Appendix A2) that confirm most of the predictions, namely that the allocation of control rights increases with commercial reputation, customer safety demands and asset specificity (IPM technical assistance). A more thorough analysis helps to differentiate the impacts of the nine independent variables on the ten dependent variables and in particular sheds light on the following aspects. First, it highlights the considerable sensitivity of the pressure of residue analysis to customer safety demands, in particular when compliance with private standards is required. Second, it invalidates the initial assumption of a strong specificity of the investment made by the marketing group in employing a quality manager considering that the investment is primarily implemented to control commercial quality which may conflict with safety quality. This finding is in line with the qualitative analysis conducted by Bonnaud et al (2012). Third, it emphasizes the role of the IPM technician who not only provides technical assistance and training, but also makes a decisive contribution to assessing the responsibility of a grower in the event of a deviant residue analysis. Fourth, it does not help draw any conclusions about the effect of group size which remains ambiguous, most likely because of a trade-off between gains obtained through economies of scale and costs to protect from potential free-riding or between control and learning.

In the Chilean case study, data analysis (see Appendix B1 and B2) highlights the existence of two clusters with contrasting safety management systems: a first cluster with buyer control focusing on the product at the delivery stage without any involvement of the buyer in the grower production process and a second cluster embedded in a close relationship with growers, with allocation of control and decision rights over the production process to the buyer and ultimately with more residue control per grower. The two clusters primarily differ in the timing of residue testing and product market orientation: while the first cluster does not take any action before the harvest, the second performs residue testing and decides the destination market of a grower's production before the harvest, partially based on such testing. Such differences illustrate the contrast between the two safety management systems. As regards the factors which may explain such a contrast, the cluster analysis illustrates that export firms in the second cluster are larger and provide growers with more training and technical assistance, in particular regarding safety management. 


\section{Discussion and implications}

\section{Discussion}

Our paper is part of an ongoing research program aimed at studying the impact of increased safety requirements on the organization of the fresh produce sector and in particular on the relationship between a grower and his buyer, irrespective of the nature of the buyer (private buyer or marketing group). In the mainstream literature, management of the health risk in agricultural production has primarily been studied from the standpoint of the individual producer (adoption of IPM practices or agricultural best practice certificates) with far less attention paid to the relationship with the buyer, i.e. from an organizational standpoint. Literature on this organizational topic is emerging for the safety domain and provides new insights that were overlooked in the mainstream literature on IPM or on the adoption of grower certificates.

On the theoretical side, our paper combines TCT, PAT and PRT to build an analytical framework to study the hybrids that govern safety management in the fresh produce grower-buyer transaction. To this end, we use the simplified model developed by Ménard (2013) which differentiates hybrids along the two dimensions that are crucial to TCT and PRT, namely ownership rights and control rights, and more precisely the strategic resources pooled by the parties and the level of centralization in the decision to manage these strategic resources. We then apply the model to the field of safety in the fresh produce sector by using data collected in two face-to-face surveys in France and Chile. In doing so, we aim to contribute to reinforcing the empirical relevancy of the Ménard model, filling the gap observed by Ménard who notes that "efforts for capturing the specificity of the arrangements within a coherent analytical framework remain underdeveloped".

Empirically speaking with regard to the health control of $\mathrm{F} \& \mathrm{~V}$, the most frequently mentioned control solutions adopted by the buyer are residue analyses and best practice certification. Buyer control of the production process and the allocation of rights to the buyer by the producer are less frequently studied. In our paper, we give insights into this allocation of rights which, according to our first observations, plays as important a role as the control over the product or over the certificate.

Both country surveys exhibit convergent findings with regard to Ménard's model despite the differences in the sets of proxies representing the main variables of the model. The main differences concerning the proxies for the allocation of decision rights are that the Chilean study has only a limited number of variables. It emphasizes residue analyses (number of analyses, timing before or after the harvest and influence on the choice of market destinations) and the technical assistance and producer training services. In contrast, the French study calls on a broader and more informative series of indicators, in particular through the modalities of sanction, the procedures of control, the involvement of the quality manager in the production process, the relationship between the technical advisor and the quality manager and 
the management of the crop sheet. The two studies nevertheless converge with regard to the importance of the possible involvement of the buyer in the production process, thereby enabling the choice of product destination to be refined to ensure increased compliance with the customer's specifications or, more generally speaking, to obtain enhanced product value in light of the existing customer portfolio.

While the four categories of strategic resources (reputation, customer safety requirements, specific assets and group size) are documented by both studies, they significantly differ in the proxies that have been found to be most relevant, as highlighted by table 1 . One of the reasons for this is again the differences in resources allocated to data collection. Another reason is the nature of the buyer (marketing group versus exporter) and the resulting level of commodity specialization of the transaction: French tomato producers' organizations mostly focus on tomatoes while Chilean fruit exporters usually buy most of the fruits that are locally grown with apples, pears, kiwis, cherries and plums among the most important.

Our empirical analysis supports the theoretical prediction of Ménard in both case studies. Although using different analysis tools (cluster analysis in the Chilean case, regression in the French case), our results confirm the relationship between the strategic resources pooled by the two parties and the level of centralization of the decision concerning the use of these resources.

The results of the few rare studies calling on Property Rights theories to analyze the relationship between strategic resources and decision rights (Arrunada et al, 2001; $\mathrm{Hu}$ and Hendrikse 2008; Windsperger, 2009) converge with those obtained from our two case studies. Differences naturally exist but these are linked to the specificity of the situations and most probably to the data available. For example, Arrunada et al (2001) use the clauses of contracts between manufacturers and car dealers and distinguish three categories of decision rights: ex-post completion rights, monitoring rights, termination rights). Windsperger (2009), who studies rights allocations in joint-ventures, focuses on knowledge assets as strategic resources pooled in the joint-venture. $\mathrm{Hu}$ and Hendrikse (2008) observe the different types of decision rights in fruit and vegetable contracts in China and highlight independent variables (quality, reputation, firm's specific assets, etc.) that are quite similar to those in our case studies, which is not surprising given the nature of the activity.

\section{Contribution to theory}

By specifying and testing the simplified model proposed by Ménard concerning the relationship between control rights and ownership rights, the key variables of Property Rights theories, we contribute to reinforcing the empirical relevancy of this model, filling the gap observed by Ménard who notes that "efforts for capturing 
the specificity of the arrangements within a coherent analytical framework remain underdeveloped".

We also contribute to fleshing out the "uncertainty" argument used by TCT to take into account the measurement issues that are central to the safety management system in the fresh produce sector. The Positive Agency Theory concepts of separability and programmability, which are used to define measurement problems and give more precision to the concept of uncertainty, help to specify our safety management model and its relevant proxies more clearly.

In light of the specificities of our safety management system, we are led to include three types of transaction costs in our model that are usually implemented separately in the analysis: the hold-up costs derived from the use of specific assets which are central to the Williamson prediction, the measurement costs that mostly derive from a heterogeneity of knowledge skills or perceptions and which are central to the Barzel TCT branch of measurement and the Positive Agency Theory, and the coordination costs derived from the perishability constraint which differ from the hold-up and measurement appropriation costs and are often forgotten in TCT (Gulati and Singh, 1998).

Finally, by exploring the details of the mechanisms that help manage the safety risk, we apply the Coase recommendation ${ }^{2}$ and thus contribute to a better understanding of the factors that can explain the intensity and diversity of decision rights in the safety management of the fresh produce sector.

\section{Managerial implications}

In the field of safety, and especially in the fresh produce sector, GAP certificates and residue testing are seen as the main control tools. Our paper adds a crucial mechanism that is most often forgotten, namely the allocation of decision rights helping buyers to control suppliers not only at the delivery stage on the platform but also in the production process.

In any management system of health risks, such as pesticide residues, affecting human health, a choice must be made between controlling the product and controlling the process which in reality corresponds to a choice between two very different operating methods: those who opt for the first choice only control the product by conducting residue analyses and by ensuring that the producers are GGcertified while those opting for the second choice also control the product but go beyond this through an involvement in controlling and taking decisions relating to production, thereby requiring human, technical assistance and training resources.

\footnotetext{
2 "An inspired theoretician might do as well without such empirical work, but my own feeling is that the inspiration is most likely to come through the stimulus provided by the patterns, puzzles and anomalies revealed by the systematic gathering of data, particularly when the prime need is to break our existing habits of thought". (Ronald Coase, prize lecture to the memory of Alfred Nobel, December 9, 1991)
} 
The ability to satisfy demanding customers depends on this capacity to become involved in the producer's decision-making process; limiting oneself to residue controls could theoretically satisfy the customer's specifications but the error risk is high in light of the measurement difficulties thereby pushing traders to guarantee themselves by also monitoring the production process.

Centralizing the decision-making process often means a loss of autonomy for one of the two parties; in the field of health, this loss of autonomy concerns the producer. As with any allocation of decision rights to one of the two parties, the other party (the producer) must receive some form of compensation. In both systems, the incentives system is poorly adapted to rewarding health quality. At best, a freeriding producer can be penalized, although is exceptional. Compensation must be found elsewhere. In the "producer groups" system, the allocation of rights is a delegation of authority to managers for a limited time period and is likely to be called into question during the general assembly. Generally speaking, the producer is not expelled from the group but has the power to influence the collective decision. In the private system, this allocation of rights lasts for a production campaign and is called into question the following year when the new contract is signed. In the case of Chile, where producers are large-scale entities, accepting an allocation of rights to the exporter is offset by the possibility for the producer to change partners the following year.

\section{Limitations}

A first limitation is methodological in nature. The limited size of the populations of buying firms is a handicap to obtaining good statistics or econometrics. There is, however, no radical solution to increase the size as in the French case, the population is almost exhaustive and in the Chilean case, the sample is half the total population. Another methodological constraint is the difficulty of access to relevant data. Primary data collection in this field is challenging as it has to be performed by means of face-to-face semi-structured interviews with managers who are usually very busy and are moreover reluctant to communicate and expand on safety issues, which have become a hot topic in our society. Duplicating such research in another country or another fresh produce sector is not easy as it requires expertise and tacit knowledge which are not always available to researchers. Other methodological limits for such research are highlighted by the second survey (Chilean case study) which did not benefit from enough time for interviews and addressed a more heterogeneous population (wide variety of fruits while the French case study focused on marketing groups specializing in tomatoes).

A second limitation relates to the approximation that commercialization rights are fully centralized by the buyer and do not influence decision rights for the safety management system. This is true for all one-tiered structures but may be different in multi-tiered structures where the marketing decision may not be fully centralized but instead be shared between the highest and intermediate levels. Our case studies are not concerned by such structures. We nevertheless had the opportunity to 
observe such marketing decentralization and its impact on safety management in other fresh produce chains ${ }^{3}$. Giving the intermediate levels a certain degree of autonomy in commercial decision-making provides strong economic incentives, in particular for management of the pesticide safety risk. Such autonomy may lead to a different allocation of control and decision rights for managing the pesticide safety risk, as predicted by our analytical framework. Sharing the marketing decision therefore becomes a crucial issue for the analysis of safety management as it may lead to a significant change in the allocation of control and decision rights for this purpose $^{4}$. It has to be included in our research program.

Another factor that was not documented in the questionnaire but that, according to our observations, may influence the choice of safety management system is grower size. In the French study, we observe the case of a marketing group with large-scale growers who pool resources to sell their production but not to recruit a technical advisor and allocate him decision and control rights over their production process. They argue that they have experience and skills to manage the pesticide safety risk on their own. Such a marketing group behaves like the firms in the first Chilean cluster and essentially limits control to residue testing as soon as the product is delivered to the packing station. Conversely, small-scale growers sometimes abandon most of their decision rights with respect to safety management, as in South Tyrol where growers have to go to the cooperative to fill the spraying machine with the chemical solution under the supervision of a technical advisor working for the cooperative. Again, this may be put on our agenda for future research.

\section{Conclusions and perspectives}

Managing the pesticide safety risk to provide end markets with safe fruit and vegetables raises complex issues due to the diversity and stringent nature of public and private safety requirements and the high cost of controlling the product and the production process. Our paper combines Transaction Cost, Positive Agency and Property Rights theories to build an analytical framework to study the hybrid forms governing safety management in the fresh produce grower-buyer transaction. To

\footnotetext{
${ }^{3}$ We observed a decentralized governance structure for marketing decisions in Blue Whale, a large-scale two-tiered French apple grower/shipper, selling the production of 10 apple producers' organizations. While the central marketing structure of Blue Whale has the delegated authority to negotiate a series of transactions (volume, variety, price, etc.) with potential customers every day, each of the ten marketing groups is allocated the right to decide which transaction(s) to honor among the series of transactions negotiated at the central level. Such a governance structure allowing intermediate levels to decide on the allocation of their own production has the advantage of enabling them to implement their own investments strategy and to allocate resources in an efficient way thanks to a good knowledge of the local safety characteristics.

${ }^{4}$ To date, however, Blue Whale is the only organization we have been able to observe with such a decentralization of the marketing decision process.
} 
this end, it uses the simplified model developed by Ménard (2013) which positions the hybrid forms along the two dimensions of decision rights and strategic resources. It then presents a selection of quantitative and qualitative findings obtained from data collected by means of face-to-face interviews with managers of fresh produce shipping firms in France and Chile.

Our results highlight how a significant increase in public and private safety requirements has led to greater integration in the supply chain and radical changes in the organization of the grower-buyer relationship, namely a tendency towards increased involvement of the buyer in the control and decision-making process relating to the grower's production. Moreover, they establish a clear distinction between firms that only control product safety at the delivery stage and firms that also control safety throughout the production process and may take decisions on behalf of the grower before harvesting.

On the theoretical side, our results are consistent with Ménard's prediction that the level of centralization increases with the level of strategic resources pooled by both parties. They show that i) stringent customer safety requirements, a good commercial reputation and more specific resources invested in technical assistance and grower control lead buyers to request greater allocation of control and decision rights from the grower; ii) otherwise, buyers do not monitor the grower's production process and limit their safety controls to the product.

Several issues have been barely explored and deserve more extensive research, for instance the issue of regulatory traceability and third-party certified GAP standards and their impact on organization. Do they allow controls and buyer involvement in the production process to be reduced or, conversely, are they a precondition for developing a more ambitious phytosanitary program and being able to serve more demanding markets?

Another interesting issue to be pursued further is the trade-off between the two types of control: control over the product and control over the process. In the French case study, we tested for the complementarity and substitutability of the two controls by examining the conditional correlations between each pair of the four strategic variables: "Pressure of residue analysis", "Sanctions", "Procedures of control over products" and "Control over practices". Our analysis requires further work, but we have already shown that there are two types of control that are substitutable and complementary. On the one hand, buyers focus either on product control or process control while on the other hand, both controls are necessary for buyers with a good reputation and demanding customers. Product control and process control are substitutes, in particular with regard to the pressure of residue analysis which may be reduced with increased control over growers' practices. Nonetheless, they are also complementary: from the moment that POs have a good commercial reputation and sell to demanding customers, both controls are necessary and cannot be exclusive. 


\section{References}

Arrunada B, Garicano L, Vazquez L (2001) Contractual allocation of decision rights and incentives: the case of automobile distribution. Journal of Law, Economics and Organization 17: $257-84$

Baker G, Gibbons R, Murphy KJ (2002) Relational contracts and the theory of the firm. The Quarterly Journal of Economics 117: 39-84

Baker G, Gibbons R, Murphy KJ (2008) Strategic alliances: Bridges between islands of conscious power. Journal of the Japanese and International Economies 22(2): 146-163

Barzel YA (1982) Measurement cost and the organization of markets. Journal of Law and Economics 25: 27-48

Barzel YA (1989) Economic analysis of property rights. New York: Cambridge University Press

Barzel YA (2005) Organizational forms and measurement costs. Journal of Institutional and Theoretical Economics 161: 357-73

Bijman J, Cechin A, Pascucci S (2013) From governance structure to governance mechanisms: Opening the black box of the member-cooperative relationship. EMNet 2013, Agadir, Morocco, November 21-23, 2013.

Bonnaud L, Bouhsina Z, Codron JM (2012) Tracer les tomates. in Bonnaud L and Joly L, L'alimentation sous contrôle: tracer, auditer, conseiller", Editions Quae, Paris (FRA), pp. $77-90$

Codron JM, Giraud Heraud E, Soler LG (2005) Minimum quality standards, premium private labels, and European meat and fresh produce retailing. Food Policy 30: 270-283

Codron JM, Bouhsina Z, Bonnaud L (2013) Collective action and allocation of decision rights in pesticide safety risk management: The case of tomato producers' organizations in France. $8^{\text {th }}$ Research workshop on Organizations and Institutions, CORS (Center for Organizsation Studies), Ribeirao Preto (BRA), October 7-8, 2013 and 140 ${ }^{\text {th }}$ EAAE seminar, Perugia (ITA), December 12-13, 2013

Dekker HC (2004) Control of inter-organizational relationships: Evidence on appropriation concerns and coordination requirements. Accounting Organizations and Society 29: 27-49

Eisenhardt KM (1985) Control: Organizational and economic approaches. Management Science 31: $134-149$

Eisenhardt KM (1989) Agency theory: Assessment and review. Academy of Management Review 14: 57-74

Engler A, Cofré-Bravo G, Codron JM, Adasme C (2016) Sanitary risk management in fresh fruit: What strategies are exporters using? Working Paper, Departamento de Economia Agraria, Universidad de Talca.

Fama EF (1980) Agency problems and the theory of the firm. The Journal of Political Economy 88: 288-307

Fulponi L (2006) Private voluntary standards in the food system: The perspective of major food retailers in OECD countries. Food Policy 31: 1-13

Goldberg V (1980) Relational exchange: Economic and complex contracts. American Behavioral Scientist 23:337-46

Grossman SJ, Hart OD (1986) The costs and benefits of ownership: A theory of vertical and lateral integration. Journal of Political Economy 94(4): 691-719

Gulati R, Singh H (1998) The architecture of cooperation: Managing coordination costs and appropriation concerns in strategic alliances. Administrative Science Quarterly 43: 781-814

Hart O, Moore J (1990) Property rights and the nature of the firm. Journal of Political Economy 98: $1119-1158$

Hendrikse G, Hippmann P, Windsperger J (2015) Trust, transaction costs and contractual incompleteness in franchising. Small Business Economics 44: 867-888 
Hobbs JE (1996) A transaction cost approach to supply chain management. Supply Chain Management: An International Journal 1: 15-27

$\mathrm{Hu}$ Y, Hendrikse GWJ (2009) Allocation of decision rights in fruit and vegetable contracts in China. International Studies of Management and Organization 39(4): 8-30

Hueth B, Ligon E, Wolf S, Wu S (1999) Incentive instruments in fruit and vegetable contracts: Input control, monitoring, measuring and price risk. Review of Agricultural Economics 21(2): 374-89

Jensen MC, Meckling WH (1976) Theory of the firm: Managerial behavior, agency costs and ownership structure. Journal of Financial Economics 3(4): 305-60

Mahoney JT (1992) The choice of organizational form: Vertical financial ownership versus other methods of vertical integration. Strategic Management Journal 13(8): 559-84

Malatesta D, Smith CR (2015) Deciding who's in charge: Factors driving the choice of decision rights in professional service contracts. Journal of Strategic Contracting and Negotiation, I (I): $65-84$

Ménard C (2013) Hybrid modes of organization: Alliances, joint ventures, networks, and other 'strange' animals. In Gibbons R, Roberts J The Handbook of Organizational Economics, Princeton University Press, Princeton 1066-1108

Ménard C (2014) Embedding organizational arrangements: towards a general model. Journal of Institutional Economics 10(4): 567-589

Ouchi WG (1979) A conceptual framework for the design of organizational control mechanisms. Management Science 25: 838-848

Richman BD, Macher JT (2008) Transaction cost economics: An assessment of empirical research in the social sciences. Business and Politics 10: 1-63

Rouvière E, Latouche K (2014) Impact of liability rules on modes of coordination for food safety in supply chains. European Journal of Law and Economics 37: 111-130

Ruben R, Boselie D, Lu H (2007) Vegetables procurement by Asian supermarkets: A transaction cost approach. Supply Chain Management: An International Journal 12(1): 60-8

Shelanski H, Klein P (1995) Empirical research in transaction cost economics: A review and assessment. Journal of Law, Economics and Organization 11(2): 335-361

Sykuta M (2008) New institutional econometrics: The case of contracting and organizations research. in Brousseau E, Glachant JM New Institutional Economics: A Textbook, Cambridge University Press, Cambridge, UK

Williamson O, (1985) The Economic Institutions of Capitalism. New York, NY: Free Press

Williamson OE (1991) Comparative economic organization: The analysis of discrete structural alternatives. Administrative Science Quarterly 36(2): 269-96

Windsperger J (2009) Allocation of decision rights in joint ventures. Managerial and Decision Economics 30: 491-501 


\section{Figures and Tables}

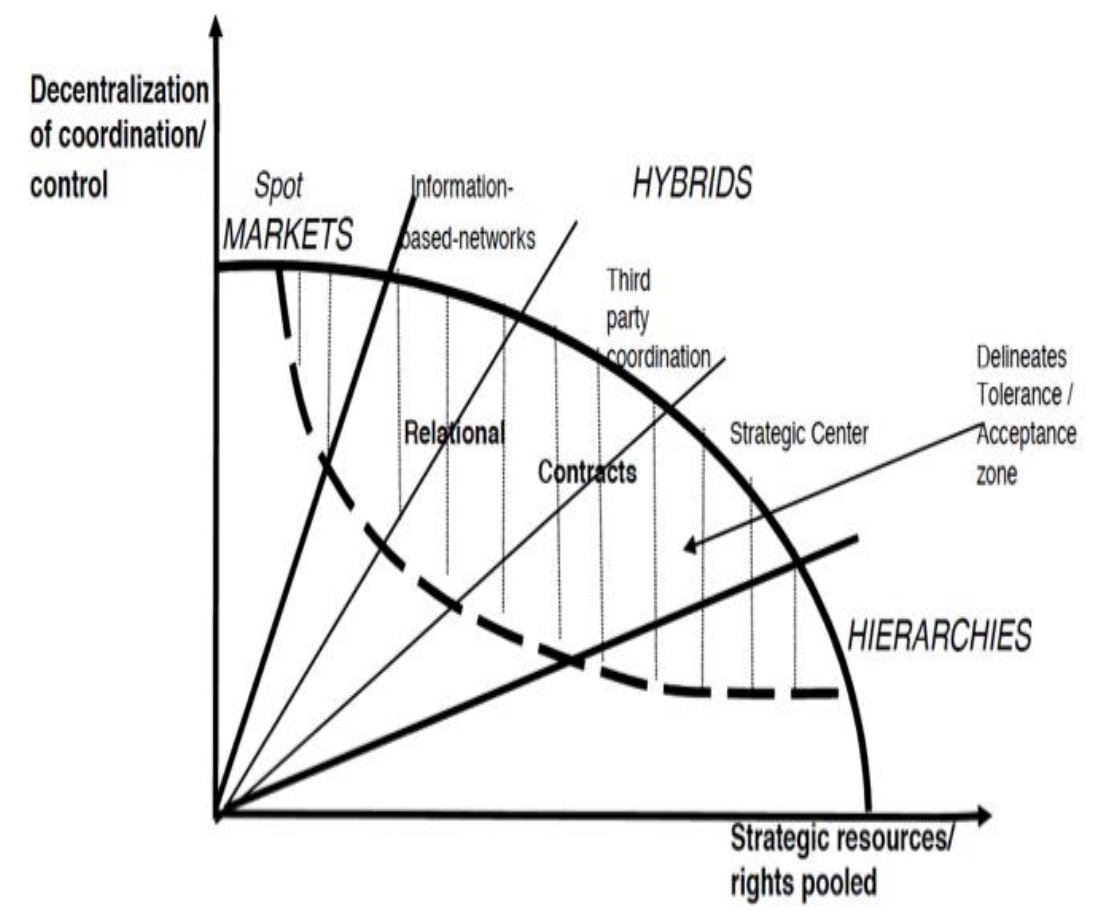

Source: Ménard in Gibbons and Roberts (2013)

FIGURE 1: POSITING THE "HYBRIDS" ALONG THE TWO DIMENSIONS OF DECISION RIGHTS AND STRATEGIC RESOURCES 


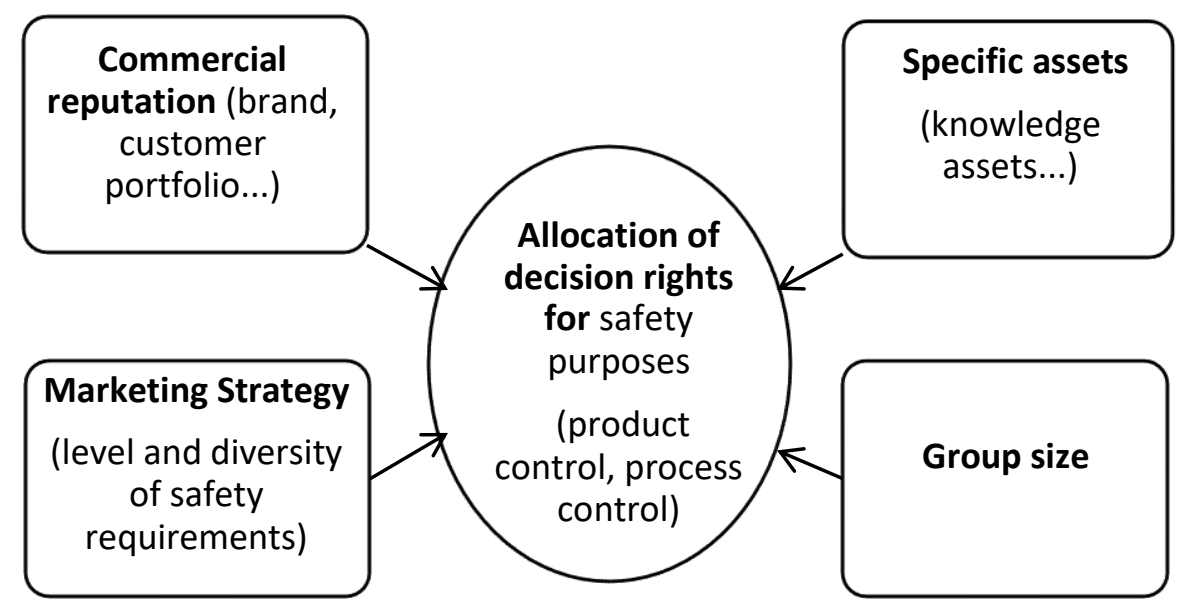

FIGURE 2: FACTORS INFLUENCING THE LEVEL OF DECISION-MAKING CENTRALIZATION FOR SAFETY MANAGEMENT 


\begin{tabular}{|c|c|c|c|}
\hline $\begin{array}{l}\text { Main } \\
\text { Theoretica } \\
\text { 1 variables }\end{array}$ & $\begin{array}{l}\text { Variables in } \\
\text { our model }\end{array}$ & Proxies in the French study & Proxies in the Chilean study \\
\hline \multirow[t]{2}{*}{$\begin{array}{l}\text { Control } \\
\text { rights }\end{array}$} & $\begin{array}{l}\text { Control over } \\
\text { the product }\end{array}$ & $\begin{array}{c}\text { number of residue } \\
\text { analysis/grower/year } \\
\text { type of penalty } \\
\text { incentives for grower } \\
\text { transparency } \\
\text { communication of } \\
\text { individual results at the } \\
\text { collective level } \\
\text { grower sampling for residue } \\
\text { analysis } \\
\text { at least one analysis per } \\
\text { grower per year } \\
\text { information/association of } \\
\text { the technician }\end{array}$ & $\begin{array}{c}\text { number of residue } \\
\text { analysis/grower/year } \\
\text { who pays for residue testing } \\
?\end{array}$ \\
\hline & $\begin{array}{l}\text { Control over } \\
\text { the process }\end{array}$ & $\begin{array}{l}\text { crop sheet management } \\
\text { consultation between the } \\
\text { QM and the IPM technician } \\
\text { frequency of greenhouse } \\
\text { visits by the QM }\end{array}$ & $\begin{array}{l}\text { role of MRL when selecting } \\
\text { destination markets } \\
\text { timing of testing residues } \\
\text { timing of the decision of the } \\
\text { destination market }\end{array}$ \\
\hline \multirow{4}{*}{$\begin{array}{l}\text { Strategic } \\
\text { ressources }\end{array}$} & $\begin{array}{c}\text { Buyer } \\
\text { reputation }\end{array}$ & $\begin{array}{c}\text { group of PO's with } \\
\text { collective brand } \\
\text { average price of tomatoes } \\
\text { per kilo/year } \\
\text { level of tomato } \\
\text { segmentation } \\
\end{array}$ & $\begin{array}{c}\text { exporter's size } \\
\text { number of market } \\
\text { destinations } \\
\text { number of fruit species } \\
\text { exported }\end{array}$ \\
\hline & $\begin{array}{l}\text { Level of } \\
\text { customer } \\
\text { safety } \\
\text { requirements }\end{array}$ & $\begin{array}{l}\text { specific safety requirements } \\
\text { in terms of pesticide } \\
\text { residues } \\
\text { fast food industry market } \\
\text { share } \\
\text { existence of UK customers }\end{array}$ & $\begin{array}{c}\% \text { of GAP certified } \\
\text { suppliers } \\
\text { buyer BRC certification } \\
\text { buyer ISO certification }\end{array}$ \\
\hline & Specific assets & $\begin{array}{c}\text { profile of the quality } \\
\text { manager } \\
\text { profile of the IPM tecnical } \\
\text { advisor }\end{array}$ & $\begin{array}{c}\text { safety technical assistance } \\
\text { training provided by the } \\
\text { buyer } \\
\text { number of growers per } \\
\text { technical adviser }\end{array}$ \\
\hline & Group size & $\begin{array}{l}\text { number of tomato } \\
\text { growers/PO }\end{array}$ & $\begin{array}{l}\text { number of suppliers } \\
\text { use of contract with } \\
\text { suppliers }\end{array}$ \\
\hline
\end{tabular}

TABLE 1: PROXIES FOR THE VARIABLES IN OUR SAFETY MANAGEMENT MODEL 
APPENDIX A1: RESULTS OF THE FRENCH CASE STUDY

\begin{tabular}{|c|c|c|c|c|c|c|c|c|c|}
\hline \multirow[b]{2}{*}{$\begin{array}{l}\text { Type of } \\
\text { control }\end{array}$} & \multirow[b]{2}{*}{$\begin{array}{c}\text { Dependent } \\
\text { Variables }\end{array}$} & \multicolumn{5}{|c|}{ Independent Variables } & \multirow[b]{2}{*}{ Intercept } & \multirow[b]{2}{*}{$\mathrm{R}^{2}$} & \multirow[b]{2}{*}{$\begin{array}{l}\text { Prob } \\
>F\end{array}$} \\
\hline & & $\begin{array}{l}\text { Group } \\
\text { Size }\end{array}$ & $\begin{array}{c}\text { Customer } \\
\text { safety } \\
\text { demand }\end{array}$ & $\begin{array}{c}\text { Commercial } \\
\text { reputation }\end{array}$ & $\begin{array}{c}\text { IPM } \\
\text { Technician }\end{array}$ & $\begin{array}{l}\text { Quality } \\
\text { Manager }\end{array}$ & & & \\
\hline $\begin{array}{c}\text { Process } \\
\text { control }\end{array}$ & $\begin{array}{c}\text { Process } \\
\text { control }\end{array}$ & 0.113 & $-0.055^{* *}$ & $0.413 * * *$ & $1.896 * *$ & $\begin{array}{c}-1.117 \\
(10.9 \%)\end{array}$ & $36.362 * * *$ & 0.635 & 0.008 \\
\hline \multirow{3}{*}{$\begin{array}{l}\text { Product } \\
\text { Control }\end{array}$} & $\begin{array}{l}\text { Analysis } \\
\text { pressure }\end{array}$ & $\begin{array}{c}- \\
0.451^{* * *}\end{array}$ & $0.010 * * *$ & $0.061 * * *$ & 0.100 & $\begin{array}{c}- \\
0.457 * * * \\
\end{array}$ & $4.234 * * *$ & 0.840 & 0.000 \\
\hline & Sanctions & $-3.477 * *$ & -0.014 & $0.513 * * *$ & $3.012 * * *$ & $\begin{array}{c}- \\
3.677 * * *\end{array}$ & $55.218 * * *$ & 0.699 & 0.002 \\
\hline & Procedures & -0.465 & 0.001 & 0.087 & $1.364 *$ & -0.597 & 11.953 & 0.251 & 0.487 \\
\hline
\end{tabular}

Significant at $1 \%(* * *), 5 \%(* *) ; 10 \%(*)$ 
APPENDIX A2: RESULTS OF THE FRENCH CASE STUDY

IN MORE DETAILS

Appendix : OLS Models Results

\begin{tabular}{|c|c|c|c|c|c|c|c|c|c|c|c|c|c|c|}
\hline \multirow[b]{3}{*}{$\begin{array}{c}\text { Independant } \\
\text { Variables }\end{array}$} & \multirow{3}{*}{$\begin{array}{c}\text { Dependant } \\
\text { Variables }\end{array}$} & \multirow{3}{*}{$\begin{array}{c}\text { Pressure } \\
\text { of } \\
\text { Analysis }\end{array}$} & \multicolumn{8}{|c|}{ Control over the Products } & \multirow{2}{*}{\multicolumn{4}{|c|}{ Control over the Practices }} \\
\hline & & & \multicolumn{4}{|c|}{ Sanctions } & \multicolumn{4}{|c|}{ Control procedures } & & & & \\
\hline & & & Aggregate & $\begin{array}{l}\text { Type } \\
\text { of } \\
\text { penalty }\end{array}$ & $\begin{array}{l}\text { Incentives } \\
\text { for grower } \\
\text { transparency }\end{array}$ & $\begin{array}{l}\text { Communication } \\
\text { of individual } \\
\text { residues } \\
\text { analysis results } \\
\text { at collective } \\
\text { level }\end{array}$ & Aggregate & $\begin{array}{c}\text { Grower } \\
\text { sampling } \\
\text { for } \\
\text { residue } \\
\text { analysis }\end{array}$ & $\begin{array}{c}\text { At least } \\
\text { one } \\
\text { analysis } \\
\text { per } \\
\text { grower } \\
\text { per year }\end{array}$ & $\begin{array}{l}\text { Information } \\
\text { on the } \\
\text { results of } \\
\text { analysis } \\
\text { and/or } \\
\text { association } \\
\text { of the IPM } \\
\text { technician } \\
\text { to control } \\
\text { planning } \\
\text { adjustments } \\
\end{array}$ & Aggregate & $\begin{array}{l}\text { Crop sheets } \\
\text { management }\end{array}$ & $\begin{array}{c}\text { Consultation } \\
\text { between } \\
\text { Quality } \\
\text { Manager } \\
\text { and IPM } \\
\text { Technician } \\
\text { over } \\
\text { residues } \\
\text { management } \\
\text { and } \\
\text { prevention }\end{array}$ & $\begin{array}{c}\text { Frequency } \\
\text { of } \\
\text { greenhouse } \\
\text { visits by } \\
\text { the QM }\end{array}$ \\
\hline & Group Size & $-0.477^{* * *}$ & $-3.477^{* *}$ & $0.874^{\circ}$ & $-0.993 *$ & 0.475 & -0.560 & -0.128 & $-1.186^{*}$ & 0.629 & 1.099 & 0.005 & $0.664^{\circ}$ & -0.251 \\
\hline \multirow{4}{*}{$\begin{array}{c}\text { level of } \\
\text { customer } \\
\text { safety } \\
\text { requirements }\end{array}$} & Aggregate & $0.010^{* * *}$ & -0.014 & 0.005 & -0.006 & 0.006 & 0.001 & -0.100 & $0.017^{*}$ & -0.003 & $-0.055^{* *}$ & -0.011 & -0.005 & -0.002 \\
\hline & $\begin{array}{l}\text { Customers } \\
\text { specific } \\
\text { requirements }\end{array}$ & $-0.200^{* * *}$ & -0.344 & 0.097 & -0.085 & -0.007 & -0.429 & $-0.634 * *$ & $0.403^{\circ}$ & -0.099 & $-1.490^{* *}$ & $-0.273^{* *}$ & -0.229 & -0.062 \\
\hline & $\begin{array}{l}\text { Share of fast } \\
\text { food industry }\end{array}$ & $0.330^{* * *}$ & 1.178 & 0.351 & -0.156 & $0.804 * *$ & -0.019 & $0.710^{*}$ & 0.504 & $-0.617^{\circ}$ & $-1.530^{\circ}$ & $-0.382^{* *}$ & -0.018 & 0.032 \\
\hline & $\begin{array}{c}\text { Export to UK } \\
\text { customers }\end{array}$ & 0.003 & -0.819 & 0.033 & -0.101 & -0.174 & 0.642 & -0.135 & -0.385 & $0.582^{*}$ & 0.452 & $0.175^{\circ}$ & -0.030 & -0.186 \\
\hline \multirow{4}{*}{ Reputation } & Aggregate & $0.061^{* * *}$ & $0.513^{* * * *}$ & 0.184 & 0.050 & $0.122 * *$ & 0.087 & -0.048 & $0.100^{*}$ & 0.178 & $0.413^{* * *}$ & 0.044 & $0.092^{* *}$ & 0.054 \\
\hline & $\begin{array}{c}\text { Membership } \\
\text { in a } \\
\text { commercial } \\
\text { superstructure }\end{array}$ & $0.346^{* * * *}$ & $2.898^{* * *}$ & 0.196 & 0.210 & $0.825^{* * *}$ & 0.087 & 0.069 & $0.455^{\circ}$ & -0.218 & $1.131^{*}$ & 0.051 & $0.309^{\circ}$ & $0.307^{\circ}$ \\
\hline & $\begin{array}{l}\text { Level of } \\
\text { tomato } \\
\text { valuation }\end{array}$ & $0.331^{\circ}$ & $3.615^{\circ}$ & -0.691 & 0.567 & 0.735 & 0.912 & 0.599 & -0.026 & 0.169 & $3.485^{\circ}$ & 0.152 & -0.201 & 0.477 \\
\hline & $\begin{array}{c}\text { Tomato } \\
\text { segmentation }\end{array}$ & $-0.166^{\circ}$ & -0.514 & 0.105 & $-0-0.072$ & -0.129 & 0.481 & 0.119 & $0.740^{\circ}$ & -0.189 & 0.925 & 0.245 & 0.119 & -0.294 \\
\hline \multicolumn{2}{|c|}{ Type of Technician } & $0.145^{*}$ & $3.012^{* * *}$ & -0.025 & $0.556^{*}$ & 0.198 & 1.483 & -0.022 & 0.231 & $0.637^{*}$ & $1.941^{* *}$ & 0.149 & $0.449^{\circ}$ & $0.447^{\circ}$ \\
\hline \multicolumn{2}{|c|}{ Type of Quality Manager } & $-0.457^{* * *}$ & $-3.677^{* * *}$ & -0.274 & $-0.557^{* *}$ & -0.381 & -0.597 & 0.037 & -0.335 & -0.307 & $-1.765^{* *}$ & $-0.237^{\circ}$ & $0.767^{* *}$ & $0.718^{* *}$ \\
\hline
\end{tabular}

Significant at $1 \%\left({ }^{* * *}\right) ; 5 \%(* *) ; 10 \%(*)$

Significant at $20 \%\left({ }^{\circ}\right)$ 
APPENDIX B1: RESULTS OF THE CHILEAN CASE STUDY

MRL management characteristics of clusters 1 and 2

\begin{tabular}{|c|c|c|}
\hline Cluster & $\begin{array}{l}\text { Low control of producer } \\
\text { MRL management during } \\
\text { production process }\end{array}$ & $\begin{array}{l}\text { High control of producer } \\
\text { MRL management during } \\
\text { production process }\end{array}$ \\
\hline $\mathrm{N}$ & 12 & 26 \\
\hline$\%$ & $31.6 \%$ & $68.4 \%$ \\
\hline Number of tests & \multicolumn{2}{|c|}{ (1) (2) $p=0.000$} \\
\hline Mean & 1.6 & 2.1 \\
\hline Who bears the testing cost & \multicolumn{2}{|c|}{ (1) (2) $p=0.052$} \\
\hline Export firms & $58.3 \%$ & $19.2 \%$ \\
\hline Supplier & $33.3 \%$ & $57.7 \%$ \\
\hline Both & $8.3 \%$ & $23.1 \%$ \\
\hline MRL criterion to decide destination market & \multicolumn{2}{|c|}{ (1) (2) $p=0.036$} \\
\hline First selection criterion & $58.3 \%$ & $50.0 \%$ \\
\hline Second selection criterion & $16.7 \%$ & $30.8 \%$ \\
\hline Third selection criterion & $8.3 \%$ & $15.4 \%$ \\
\hline Fourth selection criterion & $16.7 \%$ & $3.8 \%$ \\
\hline Timing of destination market definition & \multicolumn{2}{|c|}{ (1) (2) $p=0.038$} \\
\hline Before harvest & $16.7 \%$ & $50.0 \%$ \\
\hline At harvest & $8.3 \%$ & $19.2 \%$ \\
\hline In packing & $75.0 \%$ & $30.8 \%$ \\
\hline Timing of testing & \multicolumn{2}{|c|}{ (1) (2) $p=0.000$} \\
\hline Before harvest & $0 \%$ & $100.0 \%$ \\
\hline At harvest & $50.0 \%$ & $0.0 \%$ \\
\hline In packing & $50.0 \%$ & $0.0 \%$ \\
\hline
\end{tabular}


APPENDIX B2: RESULTS OF THE CHILEAN CASE STUDY

Main structural and management characteristics of clusters 1 and 2

\begin{tabular}{|c|c|c|}
\hline Cluster & $\begin{array}{l}\text { Low control of producer } \\
\text { MRL management during } \\
\text { production process }\end{array}$ & $\begin{array}{l}\text { High control of producer } \\
\text { MRL management during } \\
\text { production process }\end{array}$ \\
\hline $\mathrm{N}$ & 12 & 26 \\
\hline$\%$ & 31.6 & 68.4 \\
\hline Export size (in million boxes) & \multicolumn{2}{|c|}{ (I) (3) $p=0.001$} \\
\hline$<1$ & $66.4 \%$ & $42.3 \%$ \\
\hline 1 to 5 & $33.6 \%$ & $30.8 \%$ \\
\hline$>5$ & $0 \%$ & $26.9 \%$ \\
\hline Number of suppliers & \multicolumn{2}{|c|}{ (1) (3) $p=0.280$} \\
\hline$\leq 10$ & $30.0 \%$ & $14.4 \%$ \\
\hline 11 to 60 & $50.0 \%$ & $23.9 \%$ \\
\hline 61 to 99 & $0.0 \%$ & $19.1 \%$ \\
\hline$\geq 100$ & $20.0 \%$ & $42.6 \%$ \\
\hline Market destinations (number) & \multicolumn{2}{|c|}{ (I) (3) $p=0.065$} \\
\hline$<4$ & $0.0 \%$ & $0.0 \%$ \\
\hline 4 to 5 & $25.0 \%$ & $11.5 \%$ \\
\hline$>5$ & $75.0 \%$ & $88.5 \%$ \\
\hline Species (number) & \multicolumn{2}{|c|}{ (I) (3) $p=0.148$} \\
\hline 1 to 2 & $41.7 \%$ & $26.9 \%$ \\
\hline 3 to 7 & $33.3 \%$ & $15.4 \%$ \\
\hline$\geq 8$ & $25.0 \%$ & $57.7 \%$ \\
\hline Concentration degree $(\%)$ & \multicolumn{2}{|c|}{ (I) (3) $p=0.575$} \\
\hline Mean & $42.0 \%$ & $33.8 \%$ \\
\hline$\leq 21 \%$ & $20.0 \%$ & $28.7 \%$ \\
\hline $21 \%$ to $90 \%$ & $70.0 \%$ & $66.5 \%$ \\
\hline$\geq 91 \%$ & $10.0 \%$ & $4.8 \%$ \\
\hline Certified suppliers (GAP) & \multicolumn{2}{|c|}{ (1) (3) $p=0.159$} \\
\hline Mean & $79 \%$ & $89 \%$ \\
\hline$\leq 60 \%$ & $18.2 \%$ & $11.5 \%$ \\
\hline $61 \%$ to $80 \%$ & $27.3 \%$ & $7.7 \%$ \\
\hline$\geq 81 \%$ & $54.5 \%$ & $80.8 \%$ \\
\hline \multirow[t]{2}{*}{ Contract with some or all suppliers } & \multicolumn{2}{|c|}{${ }^{(1)}{ }^{(4)} p=0.503$} \\
\hline & $66.6 \%$ & $80.8 \%$ \\
\hline \multirow[t]{2}{*}{ BRC certification } & \multicolumn{2}{|c|}{ (l) (4) $p=0.503$} \\
\hline & $50.0 \%$ & $61.5 \%$ \\
\hline \multirow[t]{2}{*}{ ISO certification } & \multicolumn{2}{|c|}{ (I) (4) $p=0.632$} \\
\hline & $41.7 \%$ & $61.5 \%$ \\
\hline \multirow[t]{2}{*}{ The export firm provides technical assistance } & \multicolumn{2}{|c|}{ (I) (4) $p=0.341$} \\
\hline & $69.9 \%$ & $95.2 \%$ \\
\hline $\begin{array}{l}\text { Technical assistance in phytosanitary } \\
\text { management }\end{array}$ & \multicolumn{2}{|c|}{ (1) (4) $p=0.082$} \\
\hline
\end{tabular}


$57.1 \%$

The export firm performs training

22.5
$70.0 \%$

$75.0 \%$

11.6

1) Significance: not significant difference $=p>0.05$; significant difference $=p \leq 0.05$; very significant difference $=\mathrm{p} \leq 0.01$

(3) t-Student test

(4) Chi square test 